\title{
Erwinia carotovora contamination of Finnish seed potatoes and the prevalence of bacterial subspecies and serogroups
}

\author{
PIRKKO HARJU and JYRI KANKILA
}

\begin{abstract}
HARU, P. \& KANKILA, J. 1993. Erwinia carotovora contamination of Finnish seed potatoes and the prevalence of bacterial subspecies and serogroups. Agric. Sci. Finl. 2: 345-352. (Dept. Plant Biology, FIN-00014 University of Helsinki, Finland.)
\end{abstract}

\begin{abstract}
Symptomless contamination with the rot-inducing bacterium Erwinia carotovora was detectable by the tuber incubation method in $82 \%$ of the commercial seed potato stocks surveyed. E. carotovora subsp. atroseptica (Eca) was more common than E. carotovora subsp. carotovora $(E c c)$ among the tuber contaminants.

In a four-year survey of ten meristem-based seed stocks, recontamination with both $E c a$ and Ecc occurred typically during the second field generation, but three stocks remained free of detectable contamination throughout the survey period. The first blackleg symptoms occurred typically during the third field generation.

The serogroup distribution of Finnish Eca isolates was different from that reported from other countries. The predominant serogroup, I, constituted only $74 \%$ of all Eca isolates, since serogroups XXXV and XLI occurred relatively frequently. Serogroup I was more common among isolates from diseased stems than among those from latently contaminated tubers. The results also suggest that serogroup I is more dominant in the southern than in the northern parts of the country.
\end{abstract}

Key words: blackleg, soft rot, serology

\section{Introduction}

Potato blackleg and soft rot are caused by the bacteria Erwinia carotovora subsp. atroseptica (van Hall) Dye (Eca) and E. carotovora subsp. carotovora (Jones) Dye $(E c c)$. Both subspecies are commonly associated with tuber soft rot, but rot in the basal part of the stem (blackleg disease) is usually caused by Eca (PÉROMBELON and KELMAN 1980, PÉROMBELON et al. 1987). In warm climates, blackleg is frequently caused by E. chrysanthemi (PÉROMBELON and Kelman 1980). This species has not been found to infect potatoes in Finland, and atypical Finnish E. carotovora strains were also confirmed as not belonging to E. chrysanthemi (HARJU, unpublished).
Inoculum for the blackleg and soft rot diseases is primarily transmitted from season to season in seed tubers (PÉROMBElon 1974). Studies in Scotland (PÉrombelon 1972, 1973), Germany (FICKE et al. 1973) and the USA (DE BoER and KeLMAN 1975, NIELSEN 1978) have shown that most seed potato stocks are contaminated with E. carotovora. Also, recontamination of tubers derived from pathogenfree stem cuttings occurs soon in the multiplication process (COPEMAN et al. 1977, SAMPSON 1977, DE BOER 1983).

In Finland, the level of blackleg incidence has decreased markedly after 1976 (O. Ulvinen, pers. commun.) when the Seed Potato Centre was established to produce healthy seed potatoes by the meristem culture method (PIETARINEN and SEPPÄNEN 
1981). Nevertheless, serious blackleg problems have occurred during some exceptionally wet growing seasons.

The object of this study was to investigate the contamination by $E$. carotovora in commercial seed potato stocks and the recontamination in stocks derived from meristem-cultured plants during the multiplication process. The prevalence of the two subspecies was also investigated. Furthermore, serogroups of Eca were determined in order to get basic knowledge for the development of serological diagnostics of the blackleg pathogen.

Preliminary results of this study have been published elsewhere (HARJU and KANKILA 1987, DE BOER et al. 1987).

\section{Material and methods}

\section{Tuber samples}

In 1981-83, tuber samples of commercial stocks were collected from the stores of two starch factories in Southern Finland and those of the Seed Potato Centre, Tyrnävä. Randomly selected stocks belonged to different varieties and to the seed classes of Elite seed and Commercial seed. Furthermore, ten clones derived from meristem cultured plants were selected in 1981 for a four-year survey of Erwinia spp. recontamination.

Tubers were washed individually, pricked with sterile toothpicks and wrapped in wet paper towels. The wrapped tubers were placed in polyethylene bags and incubated for 3-4 days at $+22^{\circ} \mathrm{C}$ (DE BOER and Kelman 1975, Pérombelon 1979). Small pieces of rotting tissue were taken from every lesion in the tuber and suspended in a drop of sterile water on a glass plate. The suspension was streaked on crystal violet pectate (CVP) medium (CUPPELS and Kelman 1974) or on Stewart's medium (STEWART 1962). Pectolytic colonies typical of $E$. carotovora were restreaked and purified on Stewart's medium. Single colonies were then transferred to nutrient agar (Oxoid CM3) on which they were maintained for further examination. All cultures on agar media were incubated at $+28^{\circ} \mathrm{C}$ for $48 \mathrm{~h}$.

\section{Stem samples}

Stems were collected from potato plants exhibiting typical blackleg symptoms. Stem samples for the serogroup survey were collected from seed potato fields in the surroundings of the Seed Potato Centre and from ware potato fields of several farmers in Southern Finland (less than $200 \mathrm{~km}$ from Helsinki).

After surface sterilizing the stem with ethanol, an approx. $1 \mathrm{~cm}$ piece was cut from the rotten tissue, adjacent to the border of healthy tissue, and macerated with a glass rod or forceps in a drop of sterile water. The suspension was streaked onto the isolation medium, which was further treated as described above for tuber samples.

\section{Determination of subspecies}

Eca was differentiated from Ecc by production of reducing substances from sucrose and acid from alpha-methyl glucoside (GRAHAM 1972).

\section{Serology}

The strains which had been biochemically identified as Eca were serotyped using the Ouchterlony double-diffusion method (DE BOER et al. 1979). The antisera were kindly provided by $\mathrm{H}$. Vruggink (Institute of Phytopathological Research, Wageningen, the Netherlands) or prepared according to the method described by VRUGGINK and MAAS GeEsteranus (1975) (see Table 1). Two antisera against serogroup I, obviously having similar properties, were used because of limited availability of individual antisera.

Table 1. E. carotovora subsp. atroseptica strains used for antiserum production.

\begin{tabular}{lrll}
\hline Serogroup & Strain & \multicolumn{2}{c}{ Origin } \\
\hline I & 161 & MaasGeesteranus & Netherlands \\
I & 169 & Harju & Finland \\
XXXV & 64 & Harju & Finland \\
XLI & 281 & Lapwood & UK \\
XLIII & 10 & Harju & Finland \\
\hline
\end{tabular}


Table 2. Tuber contamination with E. carotovora in stored commercial seed potato stocks during a three-year survey.

\begin{tabular}{|c|c|c|c|c|c|c|c|}
\hline \multirow[b]{2}{*}{ Year } & \multirow[b]{2}{*}{$\begin{array}{l}\text { Seed } \\
\text { class }\end{array}$} & \multicolumn{2}{|c|}{ Number of stocks } & \multicolumn{4}{|c|}{ Contaminated } \\
\hline & & tested & $\begin{array}{l}\text { contaminated } \\
\text { with Erwinia }\end{array}$ & $\begin{array}{l}\text { No. of } \\
\text { tubers }\end{array}$ & $\begin{array}{c}\text { tubers } \\
\%\end{array}$ & $\begin{array}{l}\text { No. of } \\
\text { isolates }\end{array}$ & $\begin{array}{c}\text { Eca } \\
\%\end{array}$ \\
\hline \multirow[t]{2}{*}{1981} & Elite & 13 & 13 & 160 & 69 & 237 & 74 \\
\hline & Comm. & 18 & 18 & 200 & 77 & 408 & 78 \\
\hline \multirow[t]{2}{*}{1982} & Elite & 11 & 8 & 481 & 25 & 210 & 49 \\
\hline & Comm. & 11 & 9 & 401 & 30 & 237 & 70 \\
\hline \multirow[t]{2}{*}{1983} & Elite & 13 & 9 & 480 & 12 & 260 & 60 \\
\hline & Comm. & 5 & 1 & 180 & 4 & 18 & 17 \\
\hline \multicolumn{2}{|c|}{$\begin{array}{l}\text { Total number } \\
\text { Mean per cent }\end{array}$} & 71 & 58 & 1902 & 30 & 1370 & 67 \\
\hline
\end{tabular}

\section{Results}

E. carotovora contamination was detected in 58 of the 71 commercial seed potato stocks surveyed in 1981-83. Contamination was most widespread in the crops harvested in 1981, which was the year of highest precipitation within the period; none of the stocks surveyed in 1981 was found free of E. carotovora, and more than $70 \%$ of the total number of tubers were contaminated (Table 2). In contrast, several stocks surveyed in 1982 and 1983 did not harbor detectable levels of E. carotovora.

The blackleg pathogen, Eca, was more common than Ecc among the tuber contaminants during the whole period of 1981-83. An average of $67 \%$ of the isolates were identified as Eca. The proportion of $E c a$ among the isolates was slightly higher after the rainy summer of 1981 than during the rest of the period.

The recontamination of healthy, meristem-derived seed stocks was surveyed by subjecting ten different stocks to the tuber incubation test after each of the four first propagations (Table 3). The first propagation took place in a glasshouse, the following ones in the field. A total of 100 glasshouse-grown tubers were tested, and one of them was found contaminated by Ecc. However, neither of the subspecies could be detected in the crop of the first field generation ( 305 tubers tested). After the second field generation, five of the ten stocks were contaminated, and both subspecies were found among the contaminants, but no blackleg or soft rot symptoms were seen at this stage. The first blackleg cases were observed during the third field generation in cultivars Pito and Saturna, but not in cv. Record. Furthermore, three of the four cv. Record stocks were also free of E. carotovora contamination of the tubers.

Results of serotyping a total of $2330 \mathrm{Eca}$ isolates are presented in Table 4 . The majority of stem as well as tuber isolates belonged to serogroup I. However, in each survey year, serogroup I was more frequently found among stem isolates than among tuber isolates. Furthermore, the percentage of serogroup I among the stem isolates from Southern Finland was always close to $90 \%$, whereas the stem isolates from Northern Finland (seed production area) had a more diverse serogroup spectrum (Table 5).

Among the other serogroups, XXXV and XLI were the most frequent ones, and XLIII was rarely found. $1.5 \%$ of the isolates did not produce a homologous reaction with any of the four antisera. It was typical of the isolates to react with only one antiserum, but occasional cross-reactions were also observed.

Ecc was occasionally isolated from blackleg stems collected in Southern Finland. In each case, however, Eca was also isolated from the same stem. During the serogroup survey, no single stem was found colonised by more than one serogroup of $E c a$ (up to ten isolates per stem). 
Table 3. Contamination of ten seed potato stocks with E. carotovora during a four-year multiplication in 1981-84.

\begin{tabular}{|c|c|c|c|c|c|c|}
\hline $\begin{array}{l}\text { Stock } \\
\text { and } \\
\text { variety }\end{array}$ & Year $^{\mathrm{a}}$ & $\begin{array}{c}\text { Number } \\
\text { of } \\
\text { tubers }\end{array}$ & $\begin{array}{c}\text { Tubers } \\
\text { contaminated } \\
\%\end{array}$ & $\begin{array}{c}\text { Number } \\
\text { of } \\
\text { isolates }\end{array}$ & $\begin{array}{c}\text { Eca } \\
\%\end{array}$ & $\begin{array}{c}\text { blackleg } \\
\text { incidence }\end{array}$ \\
\hline \multirow[t]{4}{*}{ 1. Pito } & 1 & 10 & 0 & 0 & 0 & - \\
\hline & 2 & 30 & 0 & 0 & 0 & - \\
\hline & 3 & 60 & 30 & 109 & 100 & - \\
\hline & 4 & 30 & 57 & 89 & 75 & + \\
\hline \multirow[t]{4}{*}{ 2. Pito } & 1 & 10 & 0 & 0 & 0 & - \\
\hline & 2 & 30 & 0 & 0 & 0 & - \\
\hline & 3 & 60 & 5 & 7 & 29 & - \\
\hline & 4 & 30 & 30 & 52 & 81 & + \\
\hline \multirow[t]{4}{*}{ 3. Pito } & 1 & 10 & 0 & 0 & 0 & - \\
\hline & 2 & 35 & 0 & 0 & 0 & - \\
\hline & 3 & 60 & 12 & 66 & 59 & - \\
\hline & 4 & 30 & 50 & 159 & 81 & + \\
\hline \multirow[t]{4}{*}{ 4. Saturna } & 1 & 10 & 0 & 0 & 0 & - \\
\hline & 2 & 30 & 0 & 0 & 0 & - \\
\hline & 3 & 60 & 0 & 0 & 0 & - \\
\hline & 4 & 30 & 17 & 25 & 32 & + \\
\hline \multirow[t]{4}{*}{ 5. Saturna } & 1 & 10 & 0 & 0 & 0 & - \\
\hline & 2 & 30 & 0 & 0 & 0 & - \\
\hline & 3 & 60 & 13 & 50 & 76 & - \\
\hline & 4 & 30 & 27 & 79 & 88 & + \\
\hline \multirow[t]{4}{*}{ 6. Saturna } & 1 & 10 & 0 & 0 & 0 & - \\
\hline & 2 & 30 & 0 & 0 & 0 & - \\
\hline & 3 & 60 & 13 & 59 & 17 & - \\
\hline & 4 & 30 & 33 & 82 & 100 & + \\
\hline \multirow[t]{4}{*}{ 7. Record } & 1 & 10 & 0 & 0 & 0 & - \\
\hline & 2 & 30 & 0 & 0 & 0 & - \\
\hline & 3 & 60 & 0 & 0 & 0 & - \\
\hline & 4 & 30 & 0 & 0 & 0 & - \\
\hline \multirow[t]{4}{*}{ 8. Record } & 1 & 10 & 0 & 0 & 0 & - \\
\hline & 2 & 30 & 0 & 0 & 0 & - \\
\hline & 3 & 60 & 0 & 0 & 0 & - \\
\hline & 4 & 30 & 0 & 0 & 0 & - \\
\hline \multirow[t]{4}{*}{ 9. Record } & 1 & 10 & 0 & 0 & 0 & - \\
\hline & 2 & 30 & 0 & 0 & 0 & - \\
\hline & 3 & 60 & 0 & 0 & 0 & - \\
\hline & 4 & 30 & 0 & 0 & 0 & - \\
\hline \multirow[t]{4}{*}{ 10. Record } & 1 & 10 & 10 & 6 & 0 & - \\
\hline & 2 & 30 & 0 & 0 & 0 & - \\
\hline & 3 & 60 & 12 & 35 & 91 & - \\
\hline & 4 & 50 & 6 & 23 & 52 & - \\
\hline
\end{tabular}

\footnotetext{
${ }^{a}$ Year 1 , tubers raised from stem cuttings in a glasshouse. Years 2-4, tubers grown in the field.
}

${ }^{\mathrm{b}}$ Presence (+) or absence (-) of blackleg plants according to field inspection records. 
Table 4. Frequency of serogroups among E. carotovora subsp. atroseptica isolates.

a) Tuber isolates

\begin{tabular}{lcccccc}
\hline $\begin{array}{l}\text { Survey } \\
\text { year }\end{array}$ & $\begin{array}{c}\text { Number of } \\
\text { isolates }\end{array}$ & I & XXXV & XLI & XLIII & unidentified \\
\hline 1983 & 318 & 27 & 8 & 64 & 0 & 1 \\
1984 & 397 & 78 & 6 & 11 & 3 & 2 \\
1985 & 16 & 13 & 81 & 0 & 0 & 6 \\
1987 & 44 & 75 & 5 & 9 & 2 & 9 \\
\hline Total & 775 & 55 & 9 & 32 & 2 & 2
\end{tabular}

b) Stem isolates

\begin{tabular}{lrcrrrrr}
\hline $\begin{array}{l}\text { Survey } \\
\text { year }\end{array}$ & $\begin{array}{c}\text { No. } \\
\text { stems }\end{array}$ & $\begin{array}{c}\text { No. } \\
\text { isolates }\end{array}$ & $\mathrm{I}$ & XXXV & XLI & XLIII & unidentified \\
\hline 1983 & 69 & 313 & 90 & 8 & 2 & 0 & 1 \\
1984 & 111 & 654 & 92 & 5 & 0 & 2 & 1 \\
1985 & 35 & 346 & 56 & 28 & 16 & 0 & 0 \\
1987 & 41 & 111 & 92 & 5 & 3 & 0 & 0 \\
1988 & 97 & 131 & 82 & 3 & 6 & 2 & 7 \\
\hline Total & & 1555 & 83 & 11 & 4 & 1 & 1
\end{tabular}

Table 5. Prevalence of serogroup I among stem isolates of $E$. carotovora subsp. atroseptica from different geographical regions.

\begin{tabular}{|c|c|c|c|c|c|c|}
\hline \multirow[b]{2}{*}{$\begin{array}{l}\text { Sampling } \\
\text { year }\end{array}$} & \multicolumn{3}{|c|}{ Southern Finland } & \multicolumn{3}{|c|}{ Northern Finland } \\
\hline & $\begin{array}{l}\text { No. } \\
\text { ser. I }\end{array}$ & $\begin{array}{c}\text { Total } \\
\text { no. Eca }\end{array}$ & $\begin{array}{c}\% \\
\text { ser. I }\end{array}$ & $\begin{array}{l}\text { No. } \\
\text { ser. I }\end{array}$ & $\begin{array}{c}\text { Total } \\
\text { no. Eca }\end{array}$ & $\begin{array}{c}\% \\
\text { ser. I }\end{array}$ \\
\hline 1983 & 281 & 312 & 90 & & & \\
\hline 1984 & 597 & 650 & 92 & & & \\
\hline 1985 & & & & 193 & 346 & 56 \\
\hline 1987 & 102 & 111 & 92 & & & \\
\hline 1988 & 74 & 85 & 87 & 33 & 45 & 73 \\
\hline Total & 1054 & 1158 & 91.0 & 226 & 391 & 57.8 \\
\hline
\end{tabular}

\section{Discussion}

Recontamination of healthy seed potato stocks with E. carotovora occurred typically during the second field propagation. This rapid recontamination is in accordance with reports from other countries (COPEMAN et al. 1977, SAMPSON 1977, DE BOER 1983 ) and leads to the conclusion of Erwinia-free seed potatoes being very difficult to produce under field conditions, at least until further knowledge is gathered of the primary sources of bacterial inoculum.

This study did not attempt to reveal the inoculum sources, but insects (GRAHAM et al. 1976, HARRISON 1985), atmospheric aerosols (GRAHAM 1985), rain and irrigation water (QUINN 1985) have 
been indicated. The survival of E. carotovora, especially Eca, in soil is limited, but may be longer in the rhizosphere of some non-host plants (PÉROMBELON and HYMAN 1989). However, all studies on the epidemiology of $E$. carotovora have suffered from the insensitivity of detection methods. The probably minute numbers of bacteria involved in the early stages of the recontamination process can be detected and quantified only after the development of Polymerase Chain Reaction (PCR) -based methods, now underway in several countries.

It would seem logical that the pre-elite material surveyed here harbored some Erwinia bacteria already during the first field propagation, but the detection methods used were too insensitive to reveal this. The one single case of Ecc among the glasshouse-grown tubers leads one to consider the possibility of the bacteria surviving, at hardly detectable levels, through the meristem culture procedures. The results obtained by WEBER and SCHENK (1988) indicated that Eca may survive in meristem cultures without causing symptoms, and that the bacteria can be detected only after homogenization or enzymatic maceration of the plant tissue.

It should be noted, however, that discovering the primary sources of inoculum will not be the final solution to the blackleg problem. Cultural and handling practices will maintain their importance, because some blackleg bacteria will probably always be present in the environment, and poor cultivation practice will certainly allow other soft rotting bacteria (e.g. some pseudomonads) to cause problems.

Contamination with Eca and Ecc was very common in stored seed potato stocks classified as Elite seed or Commercial seed. This implies that the presence of Eca in the seed does not nearly always provoke blackleg symptoms, and stresses the importance of other health factors of the seed tuber and of the conditions in the field. The fact that contamination levels were highest after the rainy growing season of 1981 , once again points out the importance of environmental factors in the whole blackleg problem.

The results of the serogroup survey show that serogroup I, although making up the majority of Eca isolates, is not so dominant in Finland as it is in many other countries (DE BOER et al. 1987). This anomaly is significant with regard to serological detection of the bacterium. Detection systems based on serogroup I antiserum are not suitable for the situation in Finland, because the contamination would remain undetected in many cases. Since the other serogroups also are pathogenic (with perhaps minor differences in aggressiveness), they cannot be ignored when determining the health status of seed potatoes. Approaches to these diagnostic problems have been discussed elsewhere (KANKILA 1990).

The existence of the mentioned minor differences in the aggressiveness of serogroups is suggested by the observed differences between the serogroup distributions of tuber isolates and stem isolates. Serogroup I may be a slightly more potent inducer of blackleg symptoms than the other serogroups, since it was more common among stem than tuber isolates.

Another observation of potential practical significance was the stronger dominance of serogroup I in the southern than in the northern parts of the country. It should be kept in mind, however, that the sampling was not originally planned with an aim of detecting geographical differences, and a more thorough survey would be needed before drawing firm conclusions on this matter. Nevertheless, these results (Tables 4 and 5) raise questions about the significance of bacterial lipopolysaccharide (LPS) in the ecology of Eca, since the serogroups of $E c a$ are mainly based on differences in the O-chains of LPS molecules, which extend to the surface of the bacterial cell (DE BOER et al. 1985). Factors accounting for the differential success of serogroups in different regions might include, for example, humidity of the environment, frequency of freezing and thawing of the soil, and altered physiology of the host in different temperatures and daylengths.

In conclusion, $E$. carotovora is a very commonly occurring organism in the potato production system, and it would be very difficult, if not impossible, to eradicate it, but the diseases caused by the bacterium can be kept in an acceptable level. After the initiation of this study, Finnish seed potato production has developed in many respects. Cultivation and handling practices have been revised with 
an emphasis on blackleg control, and the number of field generations has been decreased. Still, blackleg problems occur in a few susceptible varieties. Advances in diagnostics may finally make it feasible to classify seed lots on the basis of their blackleg potential. Furthermore, the current breeding efforts are expected to yield more resistant varieties.
Acknowledgements. The authors appreciate the excellent technical assistance provided by Tuula Laine. The Seed Potato Centre and the Potato Research Institute are acknowledged for their co-operation. This study was financed by the Academy of Finland.

\section{References}

Copeman, R.J., Schneider, F.F. \& De Boer, S.H. 1977. Erwinia carotovora recontamination of potato tubers produced by stem cutting derived plants. Proc. Amer. Phytopathol. Soc. 4: 136-137. (Abstr.).

Cuppels, D. \& Kelman, A. 1974. Evaluation of selective media for isolation of soft rot bacteria from soil and plant tissue. Phytopathology 64: 468-475.

DE BOER, S.H. 1983. Frequency and distribution of Erwinia carotovora serogroups associated with potato in the Pemberton Valley of British Columbia. Can. J. Plant Pathol. 5: 279-284.

-, Bradshaw-Rouse, J.J., Sequeira, L. \& Mc Naughton, M.E. 1985. Sugar composition and serological specificity of Erwinia carotovora lipopolysaccharides. Can. J. Microbiol. 31: 583-586.

-, Copeman, R.J. \& Vruggink, H. 1979. Serogroups of Erwinia carotovora potato strains determined with diffusible somatic antigens. Phytopathology 69: 316-319.

— \& Kelman, A. 1975. Evaluation of procedures for detection of pectolytic Erwinia spp. on potato tubers. Am. Potato J. 52: 117-123.

一, Verdonck, L., Vruggink, H., Harju, P., Bãng, H.O. \& DE LEY, J. 1987. Serological and biochemical variation among potato strains of Erwinia carotovora subsp. atroseptica and their taxonomic relationship to other $E$. carotovora strains. J. Appl. Bacteriol. 63: 487-495.

Ficke, W., Naumann, K., Shadow, K., Móller, H.J. \& ZIELKE, R. 1973. Die Lebensdauer von Pectobacterium carotovorum var. atrosepticum (van Hall) Dowson auf dem Pflanzgut und im Boden. Arch. Phytopathol. Pflanzenschutz 9: 281-293.

Graham, D.C. 1972. Identification of soft rot coliform bacteria. Proc. 3rd Int. Conf. Plant Path. Bact., Wageningen 1971. p. 273-279.

- 1985. Spread of Erwinia bacteria in atmospheric aerosols. In: Rep. Int. Conf. Potato Blackleg Disease, Edinburgh 1984. p. 35-36.

-, Quinn, C.E. \& Harrison, M.D. 1976. Recurrence of soft rot coliform bacterial infections in potato stem cuttings: an epidemiological study on the central nuclear stock production farm in Scotland 1967-74. Potato Res. 19: 3-20.

HarJu, P. \& Kankila, J. 1987. Contamination of seed potato stocks by Erwinia carotovora in Finland. 10th Triennial Conf. EAPR, Aalborg, Denmark. Abstracts of Conference Papers and Posters. p. 430.

Harrison, M.D. 1985. Spread of Erwinia inoculum by insects. In: Rep. Int. Conf. Potato Blackleg Disease, Edinburgh 1984. p. 33-34.

KANKILA, J. 1990. Methods for the detection of serologically heterogeneous populations of Erwinia carotovora subsp. atroseptica. In: Plant Pathogenic Bacteria. Proc. 7th Int. Conf. Plant Path. Bact., Budapest, 1989. p. 889-894.

NiElsen, L.W. 1978. Erwinia species in the lenticels of certified seed potatoes. Am. Potato J. 55: 671-676.

Pérombelon, M.C.M. 1972. The extent and survival of contamination of potato stocks in Scotland by Erwinia carotovora var. carotovora and E. carotovora var. atroseptica. Ann. appl. Biol. 71: 111-117.

- 1973. Sites of contamination and numbers of Erwinia carotovora present in stored seed potato stocks in Scotland. Ann. appl. Biol. 74: 59-65.

- 1974. The role of the seed tuber in the contamination by Erwinia carotovora of potato crops in Scotland. Potato Res. 17: 187-199.

- 1979. Factors affecting the accuracy of the tuber incubation test for the detection of contamination of potato stocks by Erwinia carotovora. Potato Res. 22: 63-68.

— \& Hyman, L.J. 1989. Survival of soft rot coliforms, Erwinia carotovora subsp. carotovora and E. carotovora subsp. atroseptica in soil in Scotland. J. Appl. Bacteriol. 66: 95-106.

— \& Kelman, A. 1980. Ecology of the soft rot erwinias. Ann. Rev. Phytopathol. 18: 361-387.

-, LumB, V.M. \& ZuTRA, D. 1987. Pathogenicity of soft rot erwinias to potato plants in Scotland and Israel. J. Appl. Bacteriol. 63: 73-84.

Pietarinen, E. \& Seppänen, E. 1981. Start of seed potato production in Finland. Ann. Agric. Fenn. 20: 184-187.

QuINN, C.E. 1985. Occurrence of Erwinia bacteria in surface and underground water, rain and snow. In: Rep. Int. Conf. Potato Blackleg Disease, Edinburgh 1984. p. 43-45.

SAMPSON, P.J. 1977. Contamination with Erwinia carotovora and Verticillium albo-atrum during multiplication of pathogen tested seed potato crops, cultivar Kennebec. Am. Potato J. 54: 1-9. 
Stewart, D.J. 1962. A selective-diagnostic medium for the isolation of pectolytic organisms in the Enterobacteriaceae. Nature 195: 1023.

VRuggink, H. \& MaAs Geesteranus, H.P. 1975. Serological recognition of Erwinia carotovora subsp. atroseptica, the causal organism of potato blackleg. Potato Res. 18: 546-555.

Weber, J. \& Schenk, G. 1988. Symptomlose Ausbreitung des Naßfäuleerregers Erwinia carotovora subsp. atroseptica (van Hall) Dye an in-vitro-Pflanzen der Kartoffel. Arch. Phytopathol. Pflanzenschutz 24: 395-402.

\section{Manuscript received July 1993}

\author{
Pirkko Harju \\ Jyri Kankila \\ Department of Plant Biology \\ P.O. Box 28 \\ FIN-00014 University of Helsinki, Finland
}

Jyri Kankila

Present address:

Agricultural Research Centre of Finland

Institute of Plant Breeding

FIN-31600 Jokioinen, Finland

\title{
SELOSTUS
}

\section{Suomalaisen siemenperunan Erwinia carotovora -saastunta sekä bakteerin alalajien ja seroryhmien yleisyys}

\author{
PIRKKO HARJU ja JYRI KANKILA
}

Helsingin yliopisto

Perunan tyvi- ja märkämätää aiheuttava bakteeri Erwinia carotovora esiintyi oireettomana $82 \%$ :ssa perunateollisuuden ja Siemenperunakeskuksen varastoimista siemenperunaeristä vuosina 1981-83. Bakteerin alalajeista tyvimätäbakteeri $(E$. carotovora subsp. atroseptica, Eca) oli yleisempi kuin märkämätäbakteeri ( $E$. carotovora subsp. carotovora, Ecc).

Meristeemiviljeltyjen, terveiden siemenperunaerien saastumista tutkittiin määrittämällä tyvi- ja märkämätäbakteerin yleisyys kymmenessä siemenerässä neljänä kasvukautena. Ensimmäinen kasvukausi oli lisäys kasvihuoneessa. Bakteerisaastunta havaittiin useimmissa erissä toisen peltolisäyksen jälkeen ja ensimmäiset tyvimätäoireet kolmannen peltolisäyksen aikana. Kuitenkin kolmessa siemenerässä ei esiintynyt oireetontakaan saastuntaa koko seurannan aikana.

Eca:n seroryhmien yleisyyttä tutkittiin, jotta saataisiin perustietoa siemenerien saastuntatasoa määrittävän serologisen testin kehittämiseen. Vuosina 1983-88 määritettiin seroryhmä yhteensä 2330 Eca-isolaatista. Seroryhmäjakauma osoittautui olevan Suomessa poikkeava monissa muissa maissa vallitse- vasta. Seroryhmä I:een kuului vain $74 \%$ kaikista Eca-isolaateista, kun taas muualla sen osuus on ollut yli $90 \%$ isolaateista. Täten seroryhmä I:n antiseerumiin perustuvat kaupalliset tunnistussarjat eivät sovellu käyttöön Suomessa. Muita yleisesti esiintyviä seroryhmiä olivat XXXV ja XLI.

Seroryhmien taudinaiheuttamiskyvyssä ei ole selviä eroja, mutta seroryhmä I oli kuitenkin yleisempi tyvimätäisestä varresta kuin oireettomasta mukulasta eristettyjen bakteerien joukossa. Alustavien tulosten mukaan seroryhmä I on myös yleisempi Etelä-Suomessa kuin siementuotantoalueella.

Tuloksista voidaan päätellä, että $E$. carotovora esiintyy hyvin yleisesti perunassa ja perunan tuotantoympäristössä, mutta aiheuttaa tautioireita suhteellisen harvoin. Bakteerin täydellinen hävittäminen olisi erittäin vaikeaa tai mahdotonta. Diagnostisten menetelmien kehitys saattaa tulevaisuudessa mahdollistaa bakteerisaastunnan määrityksen kaikista siemeneristä, mutta siemenen muu kunto sekä viljely- ja varastointitekniikka säilyttävät tällöinkin merkityksensä tyvimädän ja märkämädän torjunnassa. 